\title{
Small and Medium-Sized Enterprises (SMEs), Islamic Bank, and Religiosity
}

\author{
Isnaini Harahap ${ }^{1}$, Amiur Nuruddin ${ }^{2}$, Chuzaimah Batubara ${ }^{3}$, Mhd. Syahnan ${ }^{4}$ and Sukiati ${ }^{5}$ \\ \{ isnaini.harahap@uinsu.ac.id ${ }^{1}$ \} \\ 1,2,3,4,5 Universitas Islam Negeri Sumatera Utara, Indonesia
}

\begin{abstract}
This paper attempts to examine the role played by Small and Medium-sized Enterprises (SMEs) in absorbing workforce in North Sumatra. This paper argues that the SME sector succeeded facing the impact of the economic crisis in 1998, 2008, and the European crisis in 2011. Based on the findings of this study, it can be concluded that education, labor force, financing, profit sharing, and religiosity have simultaneously given a positive impact on SMEs in North Sumatra. Even though it is influential, the coefficient of elasticity for profit, financing, education, labor force, and religiosity is inelastic towards the development of SMEs in North Sumatra. The findings imply that Islamic banks are unable to deal with the SMEs market. Thus, it requires serious attention from Islamic banks to play important role in developing SMEs in North Sumatra.
\end{abstract}

Keywords: Small and Medium-sized Enterprises (SMEs), Islamic banks, North Sumatra, Economic

\section{Introduction}

Small and medium-sized enterprises (SMEs) which are generally characterized by having low-income gains and poor management can be found in most areas in Indonesia. In North Sumatra itself, there are 1,453,063 micro business units, 698,666 small business units, and 136,574 medium business units, this sector is able to employ 625,954 people. In fact, in the middle of global financial challenges, the SME sector is able to survive compared with any other large business sectors. During the crisis of economy in 1998 and 2008, and the European crisis in 2011, the SME sector succeeded facing the impact of the economy crisis

The potential of SMEs can be used to overcome poverty, to increase economic income and the welfare of society. Unfortunately, several factors such as; the difficulty of capital resource, the limited access, and the restoration of the quality of human resources as well as the entrepreneurial skills are the obstacles to develop an SME. Therefore, it is not surprising that SMEs' capital sources are obtained from informal financing (money lenders) (Wignaraja and Jinjarak, 2015). Meanwhile, the low quality of human resources in SMEs sector is also caused by low level of education and the ability to run SMEs and these have resulted in SMEs ability to compete (Rendahnya Kualitas SDM Pengaruhi Kinerja UMKM, 2015), the limited marketing areas, and the inability of SMEs to seek new opportunities (Harlan, 2012).

In addition to the obstacles above, the lack of understanding of entrepreneurship also affects the performance of SMEs. In 2011, the level of entrepreneurship in Indonesia only reached $0.273 \%$ and it was far behind the level of entrepreneurship in Singapore (7\%) and USA (11.9\%). It proves that the biggest problem that SMEs have is a spirit to develop a business. A number of studies show that entrepreneurial spirit can be obtained from religious values (Wiseman and Young, no date) because SMEs entrepreneurs are not only workers but also people with soul, mental, and religious beliefs which affect their performance (Grine, Fares and Meguellati, 2015). 
Related to the relation between entrepreneurial spirit and religious values, many aspects of economy are now interrelated with religion. One which is very popular lately in Indonesia is the establishment of Islamic or Sharia Banking. Islamic Banking prioritizes sharia principles in its operation, such as; the interest-free (Arifin, 2002) and profit-share which help the SMEs entrepreneurs who do not want to borrow money from a bank because of its interest rates. In addition, because of its interest-free system, Islamic Banking has sharia principles that reflect religious practices. Besides, the operational principle is based on the real sector with SMEs and it is expected to be able to support the SMEs' economic growth.

Table 1. The total financing, the third-party funds, FDR sharia bank, and the sharia business unit based on city/district in the year of 2013 to November 2014

\begin{tabular}{|c|c|c|c|c|c|c|}
\hline \multirow[t]{2}{*}{ City/District } & \multicolumn{2}{|c|}{ Financing (Billion) } & \multicolumn{2}{|c|}{ DPK (billion) } & \multicolumn{2}{|l|}{ FDR } \\
\hline & 2013 & Nov 2014 & 2013 & Nov 2014 & 2013 & Nov 2014 \\
\hline Deli Serdang & 119 & 224 & 61 & 195 & $196.39 \%$ & $118.52 \%$ \\
\hline Karo & 85 & 176 & 17 & 184 & $508.42 \%$ & $96.26 \%$ \\
\hline Labuhan Batu & 383 & 50 & 181 & 10 & $210.91 \%$ & $523.21 \%$ \\
\hline Tebing Tinggi & 440 & 282 & 160 & 162 & $275.49 \%$ & $162.83 \%$ \\
\hline Binjai & 274 & 386 & 190 & 142 & $143.88 \%$ & $284.83 \%$ \\
\hline Pematang Siantar & 891 & 708 & 502 & 589 & $177.69 \%$ & $123.86 \%$ \\
\hline Sibolga & 177 & 97 & 51 & 116 & $345.50 \%$ & $88.95 \%$ \\
\hline Medan & 4.333 & 153 & 3.947 & 58 & $109.79 \%$ & $278.75 \%$ \\
\hline Padang Sidempuan & 872 & 4.511 & 450 & 4.915 & $193.84 \%$ & $91.66 \%$ \\
\hline
\end{tabular}

The financing for micro business can be seen in the following table:

Table 2. Islamic Banking Financing for Small and Medium Enterprises in North Sumatra 2012-November 2014

\begin{tabular}{lllll}
\hline \multirow{2}{*}{ Year } & \multicolumn{2}{c}{ Bus (billions) } & \multicolumn{2}{c}{ BPRS (millions) } \\
\cline { 2 - 5 } & SMEs & Other than SMEs & SMEs & Amount \\
\hline 2012 & 4.388 & 2.717 & 18.737 & 48.324 \\
\hline 2013 & 4.851 & 2.910 & 14.681 & 59.721 \\
\hline November 2014 & 3.387 & 3.955 & 12.610 & 66.713 \\
\hline
\end{tabular}

Source: Sharia Banking Statistics November 2014

Based on the data above, it can be seen that Islamic financing for SMEs in North Sumatra continues to rise. However, Is the increase in financing comparable to the improvement of SMEs' performance? With the principle of profit sharing, SMEs entrepreneurs will not be burdened by high costs of business, but the tendency of Islamic banking to set the profit sharing in accordance with the prevailing of interest rates is a topic which is important to be examined.

Based on the explanation above, this study aims to see the impact of the implementation of Islamic banking on Small and Medium Enterprises (SMEs) business sectors in North Sumatra including the impact of education, labour, Islamic bank financing, the profit sharing, and religion, on the development of SMEs in North Sumatra. 


\section{Literature Review}

\subsection{Religion and Economic}

The relation between religion and economy is an interesting topic to discuss. Literally, they are two distinct aspects of life as religion is related to the hereafter while the economy is related to worldly activities. Therefore, most people find religion and economics to have no correlation. However, essentially religion is not limited to the hereafter but also needs to be understood through understanding, interpretation, and practice of religious adherents to the teachings of religion in the form of norms, values, and ethical behaviour of their adherents in daily life (Abdullah, 2011). The internalization of the values of religious teachings that are believed to be expressed in social life (Nasution, 1973) is termed religiosity (Lubis, 2010). Glock and Stark as stated by Holdcroft develop individual religiosity into five dimensions, namely the ideological dimension (belief), ritualistic (practice), experimental (experience), intellectual (knowledge), and consequences (application or practice) (Holdcroft, 2006).

\subsection{Basic Principles of Sharia Banking}

Sharia/Islamic banking is an Islamic financial institution that plays a major role in the implementation of Islamic economic systems in Indonesia. Islamic banking (Muhammad, 2005) or interest - free banking (Arifin, 2002) is banking that operates in accordance with the principles of Shariah where operations are based on profit sharing patterns in financing, financing, and in other products (Ascarya, 2006).

To realize the implementation of sharia principles, the Islamic banking products must be completely sharia. Because the financing and financing products of sharia banks have similarities with conventional banks, the financing, and financing products in sharia banks should avoid the elements of riba (Zahrah, 1970), gharar (Sami, 2000), and maysir as well as transactions in banned businesses in Islam (Rosly, 2005) so that it is truly sharia and different from conventional banking products.

\subsection{Small and Medium-sized Enterprises (SMEs)}

Small and Medium-sized Enterprises (SMEs) or in Indonesian is popularly known as Usaha Mikro Kecil, dan Menengah (UMKM) is a business activity which is carried out by most Indonesian entrepreneurs. They are generally characterized by having low-income gains and poor management. They are also a part of the family's business with no legal entity, use simple technology and utilize local resources. Furthermore, they are also regarded as economic sectors lacking important role in supporting national economy. Because of these facts, SMEs are often called an informal sector, underground economy or extra-legal sector.

SMEs have been referred to as informal sectors since the 1970s. Hart states that "informal sector" is a part of the urban workforce outside of the public or private company sectors. It is called "informal" because it is difficult to determine its legal protection as it has no legality (Hart, 1973). According to Breman, the informal sector is unorganized, unregulated sector, and mostly legal but unregistered (Breman, 1976).

Meanwhile, the term "underground economy" or "extra-legal" sector is introduced by Hernando de Soto. He defines SMEs as an activity of producing goods and services either legally or not and separated from gross domestic product (De Soto, 1989). In addition to this, Edgar L. Feige mentions four categories of underground economy, namely; 1) Illegal economy, 2) unreported economy, 3) unrecorded economy and 4) informal economy (Feige, 1989). 


\section{Research Methodology}

This quantitative research was conducted in North Sumatra. The population was all SMEs in North Sumatra that obtains their financial capital from Islamic banking (Statistics, 2018). The SMEs are located in Medan, Deli Serdang, Binjai, Pematang Siantar, Sibolga, and Padang Sidempuan. Of the 315,273 (Dinas Perindustrian dan Perdagangan Provinsi Sumatera Utara, no date) SMEs in North Sumatra, 50 SMEs are chosen from each district above as the research sample. Therefore, the total samples of this study are 450 SMEs in North Sumatra. Of the 450 questionnaires distributed, there are only 346 data (Isaac and Michael, 1981) which can be analysed.

The data are taken by using cross-section (Suryani and Hendryadi, 2015) method and questionnaires based on Education level, the total workforce, the total financing, and the Margin level (profit sharing). To check the "religious" variable, questionnaires with 1-5 Linkert scale are used:

Table 3. The indicator of "religious" variable.

\begin{tabular}{cl}
\hline No & Religious dimension \\
\hline 1 & Ideological dimension \\
\hline 2 & Realistic dimension \\
\hline 3 & Experiential dimension \\
\hline 4 & Intellectual dimension \\
\hline 5 & Observation dimension \\
\hline
\end{tabular}

The research data were analysed using multiple linear regression methods as follow:

$\mathrm{PM}=\alpha 0+\beta 1$ Pend $+\beta 2 \mathrm{TK}+\beta 3 \mathrm{Pby}+\beta 4 \mathrm{Mrg}+\beta 5 \mathrm{Rel}+\varepsilon \ldots$

$\operatorname{LnPM}=\alpha 0+\beta 1 \mathrm{LnPend}+\beta 2 \mathrm{LnTk}+\beta 3 \mathrm{LnPby}+\beta 4 \mathrm{LnMrg}+\beta 5 \mathrm{LnRel}+\varepsilon \ldots$. (2)

Data analysis is to process data obtained from the collection results so that the results of the study can be concluded statistically or also interpreted.

\section{Discussion And Findings}

Multiple linear regression was carried out after the data met the analysis requirements, namely; the data are normally distributed, are not multi-collinearity (also collinearity) and free of heteroscedasticity. Based on the data analysis, it was found that:

\subsection{The effect of Islamic Finance, sharia Revenue sharing, Education and Labour Levels and Religiosity towards North Sumatra MSMEs} as follows:

To test this hypothesis, multiple linear regression is performed and the results obtained

Table 4. Multiple Linear Regression

\begin{tabular}{lcccc}
\hline Model & Coefficient & $\mathrm{T}$ & Sig & VIF \\
\hline Constant & 4,680 & 3,390 &, 001 \\
\hline Pend &, 022 &, 268 &, 789 & 1,231 \\
\hline TK &, 038 & 2,077 &, 039 & 1,560 \\
\hline Pby &, 501 & 12,041 &, 000 & 1,814 \\
\hline Bgh &, 010 &, 435 &, 663 & 1,081 \\
\hline Rel &, 593 & 2,567 &, 011 & 1,011 \\
\hline R & \multicolumn{5}{c}{.695} \\
\hline R Square & .483 \\
\hline
\end{tabular}




\begin{tabular}{ll}
\hline $\mathrm{F}$ & 63,520 \\
\hline
\end{tabular}

With the results above, the results of this study can be presented as follows: $\mathrm{PM}=\beta 0+\beta 1 \mathrm{Pend}+\beta 2 \mathrm{TK}+\beta 3 \mathrm{Pby}+\beta 4 \mathrm{Mrg}+\beta 5 \mathrm{Rel}+\varepsilon$ $\mathrm{PM}=4.680+0.022 \mathrm{Pend}+0.038 \mathrm{TK}+0.0501 \mathrm{Pby}+0.010 \mathrm{Bgh}+0.593 \mathrm{Rel}$

All variables have positive and significant effect on North Sumatra's SME's. It can be seen from the value of F table (63.250) and sig of .000 which shows that education, labour, financing, profit sharing, and religion have a positive and significant impact on North Sumatra's SMEs.

\subsection{The effect of Islamic Finance, sharia Revenue sharing, Education and Labour Levels and Religiosity towards North Sumatra MSMEs}

The coefficient of education, elasticity, labour, Islamic bank financing, profit-sharing, and religiosity on the development of SMEs in North Sumatra can be seen by using the following elasticity model:

$\mathrm{LnPM}=\beta 0+\beta 1 \mathrm{Pend}+\beta 2 \mathrm{Tk}+\beta 3 \mathrm{LnPby}+\beta 4 \mathrm{Mrg}+\beta 5 \mathrm{LnRel}+\varepsilon$

Which means that:

$\mathrm{LnPM}=4.680+0.010 \mathrm{Bgh}+0.501 \ln \mathrm{PbyS}+0.022 \mathrm{Pend}+0.038 \mathrm{TK}+0.593 \ln \mathrm{Rel}$

It can be seen that the coefficient of profit sharing elasticity, financing, education, labour, and religiosity is inelastic towards the development of SMEs in North Sumatra.

Specifically, the impact of education, labour, financing, profit sharing, and religiosity on North Sumatra's SMEs are as follows:

\subsubsection{Sharia Financing and SMEs (Small and Medium-sized Enterprises)}

SMEs are part of economy in Indonesia which have great potential, and they need to be supported by the adequate capital and human resources. Islamic banking as a financial institution whose missions are tijarah and tabarru contribute to the development of SMEs. However, Islamic banks are not able to provide maximum contribution to support SMEs. One of the main causes is the dominance of non-profit financing (murabahah). It can be seen from the research findings which show that out of 346 respondents, $85 \%$ of respondents choose murabahah financing, while $15 \%$ of respondents choose mudharabah and musyarakah financing.

\subsubsection{Profit Sharing and SMEs (Small and Medium-sized Enterprises)}

Profit sharing is a characteristic of Islamic banking whose amount is determined in accordance with the mutual agreement, willingness, and without any coercion. Because profit sharing is a form of investment contract, the profit sharing is not fixed and depends on the investment. This margin/profit's non-influence might be due to the reference used in determining the percentage of profit sharing in Islamic banks in the form of interest rates set by the conventional banks.

\subsubsection{Education and SMEs (Small and Medium-sized Enterprises)}

Research plays an important role in producing high quality of human resources. Although some studies show that education influences business and economic growth, the findings of this study indicate that education does not affect the income of SMEs. It can be 
strengthened by the findings that show that the types of businesses run by SMEs entrepreneurs are subsistence businesses and are intended to meet the needs of daily life. Therefore, special skills are not needed to carry out this business. In addition, most SMEs entrepreneurs were graduated from senior high schools and understand business development and marketing.

\subsubsection{Labour force and SMEs (Small and Medium-sized Enterprises)}

The labor force is an important factor in the development of SMEs. Usually, economic growth and labour force are correlated positively even though it is influenced by technology and the labour quality. In line with this opinion, the findings of this study indicate that the labor force is influencing the development of SMEs in North Sumatra.

\subsubsection{Religiosity and SMEs (Small and Medium-sized Enterprises)}

The economy is developed by religious and economic principles as the representation of Islamic teachings wholly. The results of this study indicate that religion has a positive influence on the development of SMEs. In Islamic economic, economic activities are part of Islamic teachings. The ethos of economic is formed through synergy between religious moral values and economic rationality (profit-loss). The economic and religious relationship show that SMEs are manifestations of religious practice because SMEs entrepreneurs are not only oriented to profit-loss, but also the nonmaterial aspects. The findings of this study reinforce the findings of research conducted by Muhammad Yafiz and Isnaini et.al in a study of "Matfa Society in Langkat District" which also shows that Islamic religious values and the concept of Islamic brotherhood (compassion) influence the economic growth of the community to make the economy of Matfa Society capable in carrying out economic activities and mutual prosperity.

\section{Conclusions}

Based on the research findings, it can be concluded that education, labour, financing, profit sharing, and religiosity have a positive impact on SMEs in North Sumatra. Even though it is influential, the coefficient of elasticity for profit sharing, financing, education, labour force, and religiosity is inelastic towards the development of SMEs in North Sumatra. It shows that Islamic banking is unable to support the SMEs market. Therefore, it is important for Islamic banks to strive and play important roles in the development of SMEs in North Sumatra.

\section{References}

[1] Abdullah, M. A. (2011) Studi Agama: Normativitas atau Historisitas? Yogyakarta: Pustaka Pelajar.

[2] Arifin, Z. (2002) Dasar-dasar Manajemen Bank Syariah. Jakarta: Alvabeth.

[3] Ascarya (2006) Akad dan Produk Perbankan Syariah. Jakarta: Bank Indonesia.

[4] Breman, J. (1976) "A Dualistic Labour System? A Critique of the "Informal Sector" Concept: I : The Informal Sector', Economic and Political Weekly, 11(48), pp. 1870 1876.

[5] Dinas Perindustrian dan Perdagangan Provinsi Sumatera Utara (no date).

[6] Feige, E. L. (1989) The Underground Economies: Tax Evasion and Information Distortion. Cambrige: Cambridge University Press.

[7] Grine, F., Fares, D. and Meguellati, A. (2015) 'Islamic spirituality and entrepreneurship: A case study of women entrepreneurs in Malaysia', The Journal of 
Happiness \& Well-Being, pp. 41-56.

[8] Harlan, J. (2012) Exploring the engagement of STEM SMEs with Education., The National Foundation for Educational Research. The Mere, Upton Park, Slough, Berkshire. Available at: www.nfer.ac.uk.

[9] Hart, K. (1973) 'Informal Income Opportunities and Urban Employment in Ghana', The Journal of Modern African Studies, 11(1), pp. 61-89.

[10] Holdcroft, B. (2006) "What is Religiosity?", Journal of Inquiriy and Practice, 10(1).

[11] Isaac, S. and Michael (1981) Handbook in Research and Evaluation. San Diego: EdITS Publishers.

[12] Lubis, N. A. F. (2010) Religiositas dalam Pembangunan: Upaya Mengintegrasikan Nilai-Nilai Keagamaan dalam Membangun Peradaban Manusia, dalam Rekonstruksi Pendidikan Tinggi Islam. Bandung: Cita Pustaka Media.

[13] Muhammad (2005) Manajemen Bank Syariah. Yogyakarta: Unit Penerbit dan Percetakan (UPP) AMP YKPN.

[14] Nasution, H. (1973) Islam Ditinjau Dari Berbagai Aspeknya. Jakarta: UI Press.

[15] Rendahnya Kualitas SDM Pengaruhi Kinerja UMKM (2015). Available at: http://surabaya.bisnis.com/read/20151015/8/83950/rendahnya-kualitas-sdm-pengaruhikinerja-umkm-.

[16] Rosly, S. A. (2005) Critical Issue on Islamic Banking and Financial Markets. Malaysia: Dinamas.

[17] Sami (2000) 'Towards an Objective Measure of Gharar in Exchange', Islamic Economic Studies, 7, pp. 63-67.

[18] De Soto, H. (1989) The Other Path. New York: Harper \& Row.

[19] Statistics, C. B. of (2018) The Number of Micro Enterprises in North Sumatra.

[20] Suryani and Hendryadi (2015) Metode Riset Kuantitatif: Teori dan Aplikasi pada Penelitian Bidang Manajemen dan Ekonomi Islam. Jakarta: Kencana.

[21] Wignaraja, G. and Jinjarak, Y. (2015) Why Do SMEs Not Borrow More from Banks? Evidence from the People's Republic of China and Southeast Asia. Tokyo: Asian Development Bank Institute. Available at:http://www.adbi.org/workingpaper/2015/01/09/6523.why.do.sme.not.borrow.from.banks/.

[22] Wiseman, T. and Young, A. (no date) 'Religion and Entrepreneurial Activity in the U.S.', in The Annual Proceedings of the Wealth and Well-Being of Nations. Available at:https://www.beloit.edu/upton/.../wiseman.Young.chapter.final.

[23] Zahrah, M. A. (1970) Tahapan-tahapan Pengharaman Riba (Buhus fi ar-Riba). Beirut: Dal al-Buhus al-Ilmiyah. 